\title{
THE DEGREE OF DISABILITY AND TYPES OF IMPAIRMENTS AS SELF-EMPLOYMENT DETERMINANTS OF PERSONS WITH DISABILITIES IN POLAND AND OTHER COUNTRIES
}

\author{
Andrzej Koza ${ }^{311}$ \\ https://doi.org/10.31410/itema.2018.894
}

\begin{abstract}
The purpose of the presented study is to determine whether and to what extent persons with disabilities benefited from the available support to start and continue their business activity and what barriers they encountered in the process of obtaining it.

The following research hypothesis was adopted: disability under certain socio-economic conditions can constitute an inspiration for self-employment.

The survey method, the subject literature and legal acts analysis and review method as well as the analysis of statistical data were used in the course of the study.

The commonly applied systems to increase the activity of disabled people on the labour market, and in particular aimed at providing them with incentives to undertake business activities are based on their right to work and ban on their discrimination. At the same time, various mechanisms of material encouragement for persons with disabilities, focused on stimulating such people to become active on the labour market are also applied. The main financial tools to support self-employment of the disabled people, registered as unemployed in employment offices, were subsidies for starting a business and reimbursement of some part of social security contributions. These instruments did not meet the specific needs and capabilities of persons with disabilities.

In the light of survey results conducted in 2017 in a group of 348 persons with disabilities running a business in Poland in the form of self-employment, the largest group was represented by people with moderate disability - 223 persons, which accounted for almost $61.1 \%$ of all respondents. A much less numerous group were people with a mild degree of disability - 81 persons, i.e. $23.3 \%$ respectively. The smallest group was made up of persons with the severe degree of disability - 44 people, i.e.: $12.6 \%$ of the total number of respondents.

According to the indications of the respondents, the basic source of funding for the business start-up were one's own savings and the support of the closest family members.

These sources accounted for almost $96 \%$ of all the means used to set up a business. The least frequent financial support took the form of the so-called business angels, non-governmental organizations' funding and loan funds. The subsidies for starting a business activity granted by PFRON [The State Fund for Rehabilitation of Disabled Persons] and the Labour Fund, i.e. the institutions statutorily appointed for providing support to these unemployed people who seek a way out of unemployment through self-employment, had a relatively small share. $13.51 \%$ and $8.62 \%$ of the respondents respectively, pointed to the funds received from these institutions.
\end{abstract}

Keywords: Disability, self-employment, labour market

${ }^{311}$ Wroclaw University of Economics, Komandorska 118/120, 53-345 Wrocław, Poland 


\section{INTRODUCTION}

Persons with disabilities are generally classified as disadvantaged groups on the labour market. Disability, in many cases, represents a difficult to overcome barrier in entering and persisting on the labour market. The main type of workplace for the disabled are sheltered workshops. Much less frequently this group of people decides to set up and run their own business [1]. The disabled entrepreneurs emphasize values of self-employment, pointing primarily to the possibility of self-fulfillment, improvement of their financial situation, taking better advantage of their psycho-physical abilities and social status improvement [2],[3]. Self-employment of people with disabilities also allows using the experiences of being a disabled person and designing one's work environment in an optimal way [4]. Self-employment can turn out, just like in the case of non-disabled people, the next stage in their career path and self-development [5]. Financial support received from the state and an opportunity to improve one's financial situation can also act as an incentive for self-employment of people with disabilities [6],[7]. It should be emphasized that self-employment is not a panacea, thanks to which every disabled person, or even a large part of them, can become self-sufficient and avoid the need for further help.

It should be emphasized that self-employment is not a panacea as a result of which every disabled person, or even their large group, can become self-sufficient and resign from or not require any further assistance or support. Only a small part of the discussed population may have the necessary attributes to start their own enterprise successfully. Frequently, selfemployment does not represent an alternative to a full-time job but just an existential compulsion, because the suffered disability effectively eliminates such individuals from the labour market [8].

\section{PERSONS WITH DISABILITIES AND THEIR SOCIO-ECONOMIC SITUATION IN POLAND AND OTHER COUNTRIES}

The disabled, just like non-disabled people, face similar barriers making their functioning on the labour market difficult. They also refer to entrepreneurship. International research has shown that disability has a negative impact on the situation of persons with disabilities on the labour market [9].

The experiences in analyzing the situation of people with disabilities on the labour market indicate that disability can become a significant obstacle in an effective competition on the labour market [10]. Apart from that, it is also a source of poverty and exclusion from social life. According to the data provided by the United Nations approx. $10 \%$ of the world's population, i.e. approx. 650 million people, have disabilities. The percentage of persons with disabilities goes up along with population aging. In the developing countries $80 \%$ of the disabled exist below the subsistence level or suffer poverty. The majority of the disabled in these countries live in villages and have limited access to basic goods [11]. According to the World Bank estimates, persons with disabilities make $20 \%$ of the global population suffering poverty [12]. In the European Union the situation of the disabled on the labour market is highly diversified. The common characteristics here are lower, than in the case of non-disabled persons, occupational activity, higher unemployment and poorer education [13], [14].

The programmes for employment support and counteracting social exclusion, carried out in many highly developed countries characterized by well-developed social programmes, for various 
reasons do not result in the expected effects [15]. In turn, as shown by the research results carried out in various scientific centers worldwide, self-employment of persons with disabilities can turn out an effective alternative to full-time work and an inspiration for many disabled people to return to both the labour market and the society [16],[17]. The clearly worse situation of people with disabilities on the labour market, comparing to the non-disabled ones, is commonly known and does not present any significant improvement. People with disabilities are still less professionally active and less likely to seek employment, thus they remain more at risk of unemployment, poverty and social exclusion. It is confirmed by the research results carried out in the European Union countries and the selected non-EU countries (Iceland, Switzerland, Russia, and Norway) in the years $2010-2014^{312}$ (Tab. 1).

Table 1. The selected economic activity indicators of persons with disabilities and the general population aged 20-64, in the European Union and in some countries in the years 2010 - 2014.

\begin{tabular}{|l|c|c|c|c|c|}
\hline \multirow{5}{*}{ Specification } & 2010 & 2011 & 2012 & 2013 & 2014 \\
\cline { 2 - 6 } & Employment rate & \multicolumn{5}{|c|}{ Years } \\
\hline persons with disabilities & $46.0 \%$ & $46.9 \%$ & $47.9 \%$ & $48.5 \%$ & $48.7 \%$ \\
\hline total population & $67.3 \%$ & $67.3 \%$ & $67.0 \%$ & $66.8 \%$ & $67.7 \%$ \\
\hline Unemployment rate & $18.0 \%$ & $17.4 \%$ & $18.1 \%$ & $19.0 \%$ & $19.6 \%$ \\
\hline persons with disabilities & $10.9 \%$ & $11.2 \%$ & $12.2 \%$ & $12.9 \%$ & $12.6 \%$ \\
\hline total population & \multicolumn{5}{|l|}{} \\
\hline Economic activity rate & $75.1 \%$ & $56.7 \%$ & $58.5 \%$ & $59.8 \%$ & $60.6 \%$ \\
\hline persons with disabilities & $56 \%$ & $75.8 \%$ & $76.3 \%$ & $76.8 \%$ & $77.5 \%$ \\
\hline total population & $75.5 \%$ & \\
\hline The risk of poverty and exclusion & \multicolumn{5}{|l|}{} \\
\hline persons with disabilities & $29.6 \%$ & $30.5 \%$ & $30.3 \%$ & $30.1 \%$ & $30.1 \%$ \\
\hline total population & $22.7 \%$ & $23.6 \%$ & $24.1 \%$ & $23.8 \%$ & $23.8 \%$ \\
\hline
\end{tabular}

Source: Author's compilation based on: [14]

According to the aforementioned data, the employment rate of persons with disabilities in the period 2010 - 2014 was, on average, by approx. 20 percentage points lower than in the case of total population aged 20-64. People with disabilities were at greater risk of unemployment. It is confirmed by the unemployment rate of the disabled against total population. In $2010-2014$, the average unemployment rate was more than 6 percentage points higher against that for total population. Persons with disabilities were also less active on the labour market, whereas the risk of poverty and social exclusion for economic reasons was also higher by a few percentage points.

\section{SELF-EMPLOYMENT AS THE COMPONENT OF OCCUPATIONAL REHABILITATION PROCESS OF PERSONS WITH DISABILITIES}

Disability is not only a health problem but a complex phenomenon, reflecting the interaction between the features of the person's body and the characteristics of the society in which he/she lives [18]. Persons with disabilities, in addition to their typical health problems, low self-esteem and poorer education, are continuously struggling with the problem of social and architectural barriers. It has an obvious impact on the decision of entering the path of self-employment. In the course of considering the decision to start a business, people with disabilities calculate, among others, the alternative costs. For example, if the benefits of remaining unemployed or becoming a hired labourer are higher than the profits of self-employment, it is highly unlikely that the

\footnotetext{
${ }^{312}$ No latest, complete and comparable data were available in this area.
} 
disabled person shall decide to invest in self-employment. Another factor is the degree of independence, which correlates positively with the probability of self-employment. However, the most important incentive for self-employment can take the form of self-motivation, as the factor resulting from such issues as alternative costs or independence [19].

In Poland, just as in many other countries, full-time work was the popular model of occupational rehabilitation in the years 2010-2017 (Tab. 2).

Table 2. Employed persons with disabilities and employed total population in Poland, according to

BAEL in the years 2010-2017.

\begin{tabular}{|c|c|c|c|c|c|c|}
\hline \multirow{5}{*}{ Years } & \multicolumn{5}{|c|}{ Employed persons with disabilities at working age (18-59/64) } & \multirow{2}{*}{ Unemployment rate } \\
\hline & \multirow{3}{*}{ Total } & \multicolumn{4}{|c|}{ Of which: } & \\
\hline & & \multirow{2}{*}{$\begin{array}{l}\text { Hired } \\
\text { labourers }\end{array}$} & \multicolumn{2}{|c|}{$\begin{array}{l}\text { Self-employed and } \\
\text { employers }\end{array}$} & \multirow[t]{2}{*}{$\begin{array}{l}\text { Helping } \\
\text { family } \\
\text { members }\end{array}$} & \multirow{3}{*}{$\mathrm{W} \%$} \\
\hline & & & total & $\begin{array}{l}\text { including } \\
\text { employers }\end{array}$ & & \\
\hline & \multicolumn{5}{|c|}{$\%$ of total employed persons with disabilities } & \\
\hline 2010 & 100 & 72,3 & 21,2 & 2,6 & 6,6 & 9,8 \\
\hline 2011 & 100 & 72,9 & 21,3 & 2,7 & 5,8 & 9,8 \\
\hline 2012 & 100 & 75,0 & 19,6 & 2,8 & 5,4 & 10,3 \\
\hline 2013 & 100 & 76,6 & 18,4 & 2,9 & 4,0 & 10,5 \\
\hline 2014 & 100 & 79,8 & 15,9 & 2,5 & 4,2 & 9,2 \\
\hline 2015 & 100 & 82,6 & 14,1 & 2,4 & 3,8 & 9,3 \\
\hline 2016 & 100 & 85,5 & 12,1 & 1,7 & 2,4 & 6,3 \\
\hline 2017 & 100 & 86,4 & 11,3 & 1,6 & 2,3 & 5,0 \\
\hline Years & \multicolumn{5}{|c|}{ total working age population (18-59/64) } & $\mathrm{x}$ \\
\hline 2010 & 100 & 77,0 & 19,1 & 4,2 & 3,9 & 9,8 \\
\hline 2011 & 100 & 77,1 & 19,1 & 4,2 & 3,7 & 9,8 \\
\hline 2012 & 100 & 77,6 & 18,9 & 4,2 & 3,5 & 10,3 \\
\hline 2013 & 100 & 78,2 & 18,5 & 4,2 & 3,3 & 10,5 \\
\hline 2014 & 100 & 78,6 & 18,3 & 4,1 & 3,1 & 9,2 \\
\hline 2015 & 100 & 78,8 & 18,3 & 3,9 & 3,0 & 9,3 \\
\hline 2016 & 100 & 79,3 & 18,1 & 4,0 & 2,6 & 6,3 \\
\hline 2017 & 100 & 79,6 & 17,8 & 4,0 & 2,6 & 5,0 \\
\hline
\end{tabular}

Source: Author's compilation based on: [20].

In turn, a particular situation can be identified in which persons with disabilities were more willing, than the total population at working age (18-59 for women and 18-64 for men), to take up self-employment. The immediate factor affecting labour market activity and the type of job preferred is actually the situation occurring on the discussed market. High unemployment rate constitutes an important incentive for people with disabilities to seek employment in the form of self-employment as an alternative to a full-time job. In 2010-2013, i.e. in the period of unemployment rate in Poland at the level of $10 \%$, on average $20.1 \%$ of the employed persons with disabilities were running a business, which is on average 1.2 percentage points more than in the case of total Polish population at working age. The labour market situation improvement - a decline in unemployment rate affected lower interest of the disabled in running their own business. It was particularly evident in the years 2013-2017. In this period, the systematically decreasing unemployment rate coincided with a significant decline in the percentage of persons with disabilities running their own enterprise. In the case of total population, the decline rate in the percentage of people running their own businesses in the discussed period amounted to only 0.7 percentage points, which was much lower than in the case of people with disabilities. 


\section{THE DEGREE OF DISABILITY AND TYPES OF IMPAIRMENTS VS. SELF- EMPLOYMENT IN THE LIGHT OF SURVEY RESULTS}

The disability rating system in force in Poland, i.e. granting a disabled individual with the legal status of a person with disability recognizes a disabled person as the one who has a valid disability certificate issued by the competent assessing and decision-making authority [21]. In the light of the decisions made, a disabled person can be classified as having one of three disability degrees, i.e. a severe, moderate or mild degree of disability. A person with disability may be diagnosed with one or more medical conditions presenting varying degrees of intensity. A disabled person may also suffer from a particular or a special type of impairment, which entitles him/her or their employers to additional benefits or privileges [see 22 and 23].

In the light of survey results conducted in 2017 in the group of 348 persons with disabilities running a business in the form of self-employment, the largest group covered persons with moderate disability -223 people, which accounted for almost $61.1 \%$ of all the respondents (Fig. $1)$.

Figure 1. The structure of persons with disabilities covered by the survey taking into account the degree of disability

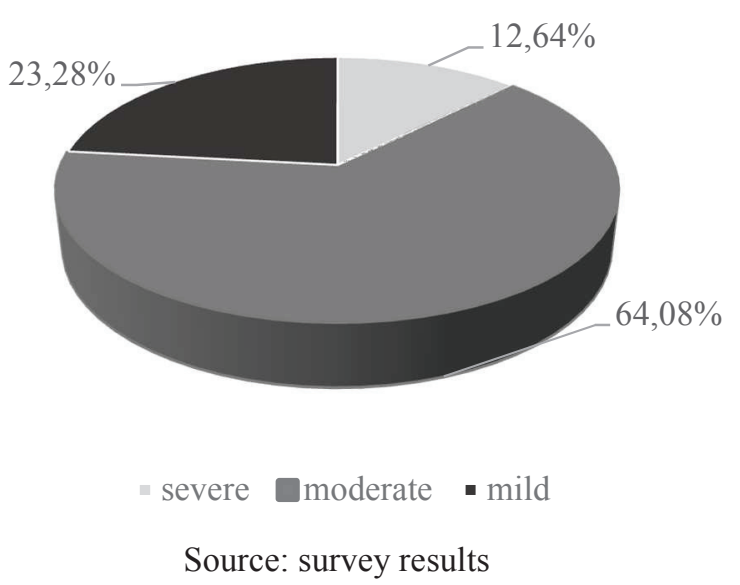

The less numerous group was made up of persons with mild degree of disability - 81 people, which accounted for almost $23.3 \%$ of the people surveyed. The smallest group included the most disabled people, i.e. with a severe degree of disability -44 people, i.e. over $12.6 \%$ of all the respondents.

The survey results indicated a significant diversification in the population of persons with disabilities running a business and covered by the survey in terms of the diagnosed impairment type. It should be remembered that part of the respondents suffered from at least one impairment. Hence, the sum of the results exceeds $100 \%$. The summary of the conducted survey results allows identifying the locomotor disorder as the most frequent one among the respondents who were running a business on their own account in the form of self-employment (Fig. 2). 
Figure 2. The structure of persons with disabilities covered by the survey taking into account the type of disability

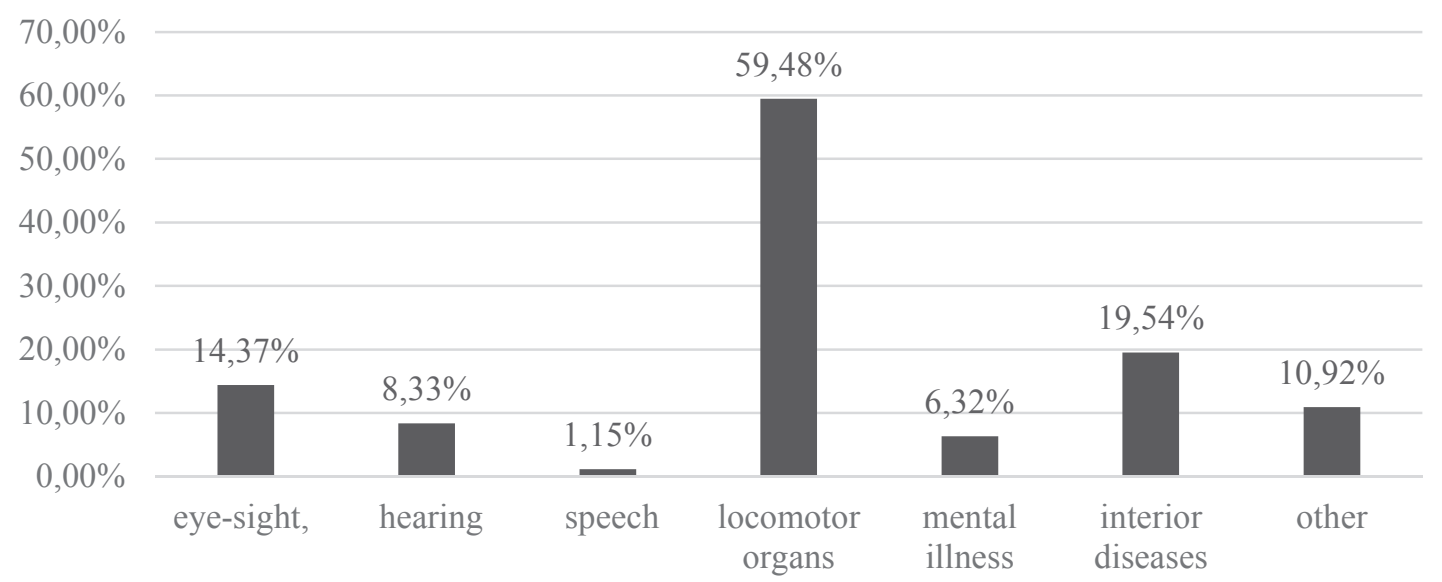

Source: survey results.

As many as 207 respondents out of 348 people surveyed, i.e. approx. 60\%, indicated this impairment type. The least often indicated was mental retardation - only one person $(0.29 \%)$. Mental retardation was the least frequently marked disorder - only one person $(0.29 \%)$. The indication of the locomotor organs disorder as the most conducive - even stimulating persons with disabilities for self-employment seems obvious. Mental disorders and problems with speech, i.e. verbal communication with the environment, can also be considered the most significant barriers in running a business by people with disabilities.

\section{CONCLUSION}

The purpose of the presented study was to identify whether there was a relationship between the degree of disability and the type of the suffered impairment as well as the tendency towards taking up the risk of running a business in the form of self-employment.

It was adopted in the study that some types of impairments and their intensity could become, under specific conditions, the factor motivating persons with disabilities to take up selfemployment.

The general situation on the labour market and specifically the level of unemployment was definitely the major determinant influencing active attitudes of persons with disabilities on the labour market, predominantly in terms of running a business in the form of self-employment. In the case of Poland, the growing and generally high unemployment rate in 2010-2013 was an incentive for people with disabilities to look for their place on the labour market through selfemployment, rather than with reference to the overall Polish society. In the period of unemployment rate decline recorded in the following years, the percentage of persons with disabilities running their own businesses (both in terms of the total population and the disabled) was systematically decreasing, however, in the case of persons with disabilities, the rate of decline was definitely higher.

In the years 2010-2017 the situation of the disabled in terms of running a business in the form of self-employment also depended on the type of suffered impairment and the degree of disability. In the light of the conducted survey results, covering 348 persons with disabilities running a 
business in the form of self-employment, the highest percentage (over 64\%) was characterized by a certified moderate degree of disability. The smallest percentage referred to the most severely disabled persons (almost 13\%). It is well understandable, taking into account the fact that such persons, in the light of the aforementioned provisions on declaring disability degrees, were often characterized by the impairments preventing their independent existence or requiring permanent care of an assistant, medical consultation and care as well as an intensive rehabilitation process. People with mild disability, theoretically the most independent both physically and mentally, thus predestined for self-employment, accounted for slightly over $23 \%$ of the respondents. It can, therefore, be adopted that it was much easier for them to find full-time employment than in the case of either moderately or severely disabled people. The respondents most often indicated the disorders of locomotor organs and internal diseases as the reasons for their disability. In total, these individuals accounted for as many as $80 \%$ of the overall number of the surveyed population running their own business in the form of self-employment. People suffering from mental disorders and speech impairments were the least frequent to run their own companies. Thus, it can be assumed that mobility problems and verbal communication dysfunctions constituted an incentive for undertaking a business activity, while mental disorders and speech impairments acted as destimulants.

In the light of the conducted surveys, the subject literature studies and the statistical data analyses, the research hypothesis was positively verified.

\section{REFERENCES}

[1] Gittlieb A., Myhill W. N., Blanck P., Employment of People with Disabilities, International Encyclopedia of Rehabilitation, Center for International Rehabilitation Research Information and Exchange (CIRRIE), New York, 2015.

[2] Boylan, A. and Burchardt, T. Barriers to self-employment for disabled people, Report for the Small Business Service 2002, Pobrano z: http://www.berr.gov.uk/files/file38357.pdf. (Accessed: 12.05.2018r)

[3] Pagan R. Self-employment among people with disabilities: evidence for Europe, Disability \& Society Vol. 24, No. 2, March 2009, pp. 217-229.

[4] Office of Disability Employment Policy. United States Department of Labour. SelfEmployment for People with Disabilities, 15 of December 2013.

[5] Bruce, D., Schuetze H. The labour market consequences of experience in self-employment. Labour Economics 11, Elsevier 2004, pp. 597-598.

[6] Clark, D., and S. Drinkwater. Ethnicity and self-employment in Britain. Oxford Bulletin of Economics and Statistics 1998, pp. 383-407.

[7] Koza A. Źródła zasilania finansowego niepełnosprawnych przedsiębiorców w świetle zmian ustawowych, Uwarunkowania Rynkowe Rozwoju Mikro i Małych Przedsiębiorstw. Ekonomika i Organizacja Przedsiębiorstwa, Numer Specjalny Maj 2008, Instytut Organizacji i Zarządzania w Przemyśle „ORGMASZ”, pp. 46-50.

[8] Malcolm H, Momm W., Self-Employment for Disabled People - Experiences from Africa and Asia (ILO, 1989),

[9] Jones, M. 'Disability and the Labour Market: A Review of the Empirical Evidence', Journal of Economic Studies 35,5, 2008, pp. 405-424.

[10] Berthoud R. Disability Employment Penalties In Britain 2008, Work, Employment And Society, Vol 22(1), pp. 129-148.

[11] ILO. Media Guidelines For The Portrayal Of Disability. International Labour Organization. Geneva, 2010, pp.11.

[12] World Bank, http://youthink.worldbank.org/issues/ disabilities. (Accessed: 04.05.2017r.). 
[13] Shima I., Zolyomi E., Zaidi A.. The Labour Market Situation of People with Disabilities in EU25. European Centre of Social Welfare Policy and Research. Policy Brief February (I) 2008 , pp.4.

[14] Grammenos S. ANED -Academic Network of European Disability Experts, European comparative data on Europe 2020 \& People with disabilities. Final report January 2017.

[15] Larsson S. Disability Management and Entrepreneurship: Results From a Nationwide Study in Sweden International Journal of Disability Management, Vol. Issue 1, 01 May 2006, pp. 159-168.

[16] Yamamoto S., Unruh D. Bullis M., The viability of self-employment for individuals with disabilities in the United States: A synthesis of the empirical-research literature, Journal of Vocational Rehabilitation 35 2011, pp. 117-124.

[17] Kitching J., Entrepreneurship and self-employment by people with disabilities, OECD $2014 \mathrm{r}$.

[18] UNIC WARSAW Ośrodek Informacji ONZ, http://www.unic.un.org.pl/niepelnosprawnosc/ definicja.php. (Accessed: 15.05.2018.).

[19] Vaziri D., Schreiber D., Wieching, R., Wulf V., Disabled entrepreneurship and selfemployment: The role of technology and policy building, OECD Geneva 2014, pp.2-4.

[20] GUS BAEL https://stat.gov.pl/obszary-tematyczne/rynek-pracy/pracujacy-bezrobotnibierni-zawodowo-wg-bael/aktywnosc-ekonomiczna-ludnosci-polski-iv-kwartal-2017roku,4,28.html (Accessed: 10.05.2018r.).

[21] Act of 27 August 1997 on vocational and social rehabilitation and employment of disabled people, Dz. U. z 2018 r. poz. 511.

[22] Koza A. Niepełnosprawni i ich konkurencyjność na rynku pracy, Studia Ekonomiczne. Zeszyty Naukowe Uniwersytetu Ekonomicznego w Katowicach nr 293, Katowice 2016.

[23] Koza A. Ulgi we wpłatach i ich konsekwencje dla sytuacji finansowej Państwowego Funduszu Rehabilitacji Osób Niepełnosprawnych, Prace Naukowe Uniwersytetu Ekonomicznego we Wrocławiu nr 478, Wrocław 2017. 